\title{
Remixing Interculturality, Youth Activism and Empire A Postcolonial Theological Perspective Reggie Nel ${ }^{1}$
}

\begin{abstract}
The struggles of youth and student activist movements of have radically challenged theology. For some (as an act of repentance) Theology, and in particular Missiology, are to be discarded or renamed as Intercultural Theology, for others Public Theology. This article wants to engage these proposals, by firstly affirming the particular agency of young activists, in South Africa, as they remix social activism and theology, but it probes deeper into the contemporary challenge of youth activism against Empire, in order to provide a particular perspective on this renaming. The author argues for a postcolonial theological perspective, or Postcolonial Theology, which takes serious the insights from new social movement theory, in their challenge of Empire. It is from this perspective where interculturality and youth activism, in the face of empire, is remixed towards transformation.
\end{abstract}

Keywords: Intercultural Theology, interculturality, youth activism, empire, missiology, postcolonial theology.

Whether it was the voices of Dietrich Bonhoeffer, Steve Biko or even Jesus Christ himself, status quo theologies are often challenged and fundamentally transformed by young activists. It still happens today. Lydia Khalil ${ }^{2}$, a journalist, tells the remarkable stories of unknown young people as they were transforming their world. Their significance - which captivated the imagination of her readers - is their relation to what became known popularly and celebrated a few years ago, as the "Arab Spring"'3. She tells the story of Neda-Agha Soltan, from Iran,

An aspiring musician and a 27-year-old graduate student who worked at her family's travel agency. One day she happened upon one of the many groups of protest-

1 Reggie Nel, Associate Professor at the Department of Christian Spirituality, Church History and MissioIogy, University of South Africa, Pretoria. <rwnel@unisa.ac.za>

2 "Youthquake in the Middle East." http://www.theaustralian.com.au/news/arts/youthquake-in-themiddle-east/story-e6frg8nf-1226033191650?utm_source=twitterfeed\&utm_medium=twitter [Accessed 6 April 2011].

3 Alcinda Honwana, "Youth and Revolution in Tunisia”, (London New York: Zed Books, 2013), 1; Joerg Rieger and Kwok Pui-lan, "Occupy Religion: Theology of the Multitude", (Lanham Boulder New York Toronto Plymouth: Rowman \& Littlefield Publishers, 2012), Loc. 77 [Kindle Edition] 
ers that had taken to the streets of Tehran that summer of 2009. One minute she was milling about with her friends, shielding her eyes from the sun as she observed from the side-lines the chanting protesters and commotion, the next minute she was slumped to the ground, blood spewing from her face and nose. A stranger captured her death on a mobile phone and later that day the amateur videographer uploaded the video of Soltan's murder to YouTube. The scene of her death was played again and again on computer and telephone screens all across Iran and the world. She became an accidental martyr for the Iranian opposition movement.

And then Khalil tells the story of Mohammed Bouazizi, from Tunisia

Bouazizi came from a large Tunisian family of six brothers and sisters. They lived modestly in the backwater of Sidi Bouzid where job opportunities were few. When he was a young boy, his father died, forcing Bouazizi to sacrifice his already mediocre education in a one-room school to take on a job to support his family. The best work he could come up with was selling fruit at the market, but even then he could not afford an official permit. With his meagre salary as an illicit fruit vendor, he paid for his sisters' college fees and attempted to save up for a work van ... As he was setting up one morning to sell his wares, a female inspector came up to fine him for selling without a licence. When he protested, she slapped him, humiliating him in front of the entire market. When he tried to complain to the local authorities, no one would take his meeting. Desperate and incensed, he doused himself with petrol and set himself on fire in front of the municipal building. He died 18 days later ... The wave of Arab revolt was sparked in the most obscure, backwater town in the margins of Middle East. It was done by someone with no history of political protest or activism. Bouazizi was a nobody, really, until his tragedy provoked an irresistible movement for change across the Arab world.

What happened here? How are we to assess these? Khallil offers an explanation,

Soltan, Bouazizi ... were unknown, ordinary young people; anonymous members of the masses. Their lives were not marked by anything in particular but their deaths carried a potent symbolism: they came to symbolise the anonymous, persistent struggles of their generation against authoritarianism. These victims and the anonymity of the internet allowed masses of $s h a b a b^{4}$ to coalesce around symbolic figures to give themselves a voice, a voice that was not easily detected by the state [Emphasis added].

4 Khallil translates shabbab as simply "the youth". This reference, which is simply a translation, should however not be confused with the name "al-Shabab" which is a militant group based in Somalia, which claimed responsibility for various attacks in Somalia and Kenya. 
The critical question, broadly, is how these "persistent struggles of their generation", i.e., these new waves of youth activism, continues to challenge and have the potential to transform the way theology (whether, amongst others in Christianity, Judaism or Islam) is done today 5 . Related to this question and more specific to this contribution, is how we are to put into perspective, the [recent] proposals of the notions of "Public" and "Intercultural", as adjectives to Theology - as attempts to continue the dialogue or, responds to the challenges raised by, amongst others, the various expressions of Liberation Theology ${ }^{6}$ in its confrontation of the status quo or colonial, imperialist Theology? In this contribution, I narrow my focus down to Intercultural Theology.

With this question in mind, I endeavour to critically engage these recent proposals, on the basis of a dialogue with these new generations of young activists. In doing this from a postcolonial perspective, I briefly reflect firstly on my own (southern) African trajectory, challenged by the questions raised in the (northern) African youth uprisings referred to in the introduction. This section works self-reflexively and critically, from this particular colonial reality and inherently, missiological trajectory. Secondly, I reflect on the proposals reacting to these challenges, and finally aim at an understanding of the way it is to shape how we are remixing the proposals for Postcolonial Theology which take serious the challenges of Interculturality, Youth Activism in a context of Empire.

\section{Youth Activism, remixing (southern) African Theology}

Being born in the late 1960s, it has become a commonplace to state that my generation grew up in and experienced fundamental transformation globally as well as in (southern) Africa. We struggled with the explosion of mass culture, as the US backed entertainment industry, but also, its imperial military and economic conquest $^{7}$ shaped our lives. It was from this context where youth and student activism

5 This article is primarily based on my DTh thesis, in Reginald W. Nel, Discerning an African Missional Ecclesiology in Dialogue with two Uniting Youth Movements (Unpublished Doctoral Thesis, Pretoria: University of South Africa, 2013), but continues my reflections on nurturing a dialogue with youth movements.

6 "Mission Studies as Intercultural Theology and its Relationship to Religious Studies", http://www. dgmw.org/MissionStudies.pdf [Accessed 06 Feb 2015]; Werner Ustorf, "The Cultural Origins of "Intercultural Theology", Mission Studies, 24:2 (2008), 229; Vuyani Vellem, "Allan Aubery Boesak: "A Black Public Theologian from the Belle of a Kgodumodumo", in Prophet of the South: Essays in honour of Allan Aubrey Boesak, edited by Prince Debeela, Puleng Lenkabula and Vuyani Vellem, (Johannesburg: UCCSA Publications, 2012), 406-409

7 Sampie Terreblanche, "A History of Inequality in South Africa 1652-2002" (Pietermartizburg: University of Natal Press, 2002), 306-312; Allan Boesak, Johann Weussman, Charles Amjad, eds., "Dreaming of a Different World: Globalisation and Justice for Humanity and the Earth: The Challenge of the Accra Confession for the Churches" (The Globalisation Project: Evangelish-reformierte Kirche, Germa- 
against a particular expression of imperialism emerged, fundamentally challenging the universality in theological expression but also the "neutrality" or "innocence" of the mission churches and the theologies alike ${ }^{8}$. For these mostly younger Christians from the global South, this conscientization meant a "farewell to innocence" and a close identification with what became known as the black expressions of, and the struggle for selfhood and self-determination. The Black Consciousness Movement (BCM), in particular, led by student leader Steve Bantu Biko and others in the early 1970s spurred on, the 1976 youth revolts and later the various school, sports and consumer boycotts of the 1980s, which in its complexity and often raw contestations, deeply transformed childhood, educational and in particular church experiences. At the time then, proponents of South African Black Theology, in particular pleaded for "a Christian presence in the struggle" and defined their theological task in dialogue with these youth and student activists and movements. ${ }^{9}$

What is often under-emphasised in theological discourse, however, is also the reality that in the local townships and rural towns, a particular expression of culture, or in the words of Biko, a "modern African culture" or "modern black culture"10, through music, movies and fashionable styles from the African diaspora, i.e., AfroAmerican, Afro-Brazilian and the Caribbean styles, played key roles in how South African black young people, in particular, perceived and made meaning out of our world ${ }^{11}$. This mixing, or the development of "joint cultures of the communities"12 in the struggle, but also, solidarity, exchange and borrowing from the popular strug-

ny Uniting Reformed Church in Southern Africa, 2010), 24-26; Ninan Koshy, "The global empire: an overview", Reformed World 56:4 (2006), 335-345; Muto Ichiyo, "The American empire in historical perspective", Reformed World 56:4 (2006), 349-352; Sampie Terreblanche, "The Second Meltdown of the Ideology of Market Fundamentalism", Reformed World 59:1 (2009), 3-6.

8 Allan A Boesak, "Farewell To Innocence: A Social-Ethical Study of Black Theology and Black Power", (Johannesburg: Raven, 1977).

9 Allan A. Boesak, "The Black Church and the Future", in "Black and Reformed: Apartheid, Liberation and the Calvinist Tradition" (Johannesburg: Skotaville Publishers, 1984), 27; "Sources of Resistance and Defiance: Radical Christianity and a Theology of Refusal", in Running with Horses: Reflections of an Accidental Theologian, (Cape Town: Joho Publishers, 2009), 46-47; Takatso Mofokeng, "The Crucified amongst Crossbearers: Towards a Black Christology", (Kampen: J.H.Kok, 1983), 6-10, 1419; Tinyiko Maluleke, "May the Black God stand please! Biko's challenge to Religion", in The Legacy of Stephen Bantu Biko: Theological Challenges, edited by Cornel du Toit (Pretoria: Thabang Printers, 2008), 57-72;

10 Steve B. Biko, "I write what I like" (Johannesburg: Picador Africa, 1978), 45, 50-51.

11 Biko, "I write what I like", 106; Zimitri Erasmus (Ed), "Coloured by History, Shaped by Place: New perspectives in Coloured Identities in Cape Town", (Cape Town: Kwela Books), 22; See also Robert J. Schreiter, "Constructing Local Theologies", (Maryknoll, Orbis Books, 1996), 12-13, for how this impacts on theological expression, and the distinction between the focus on cultural identity, as well as on oppression and social ills. I critique this perspective later in the article.

12 Biko, I write what I like, 50; See also, Frans Wijsen, "Intercultural Theology and the Mission of the Church", Exchange 30, no.3 (2001), $220 \mathrm{f}$. 
gles in Latin-America, was confirmed in the last three years, in the collaboration and exchange between researchers from South Africa and Brazil, on the themes of citizenship, interculturality and the role of Public and Intercultural Theologies. It is in this collaboration that this article was tested and debated, and in relation to this context that I then prefer to appropriate the musical metaphor of "remixing"13.

Remixing is a metaphor for what became known as "contextualization". For me, it better articulates the artistic and creative agency, in particular of younger generations, as they freely appropriate samples from various cultural and political sources to respond to, but also, to rebel or revolt against domination. The idea to use "remixing" in this theological context, as I have used it so far in my own research and therefore in this article, is however not new at all $^{14}$. Walsh and Keesmaat ${ }^{15}$ also use remixing in the context of hermeneutics and the re-reading of the biblical text within the context of globalisation and Empire. They explain,

The idea of "remixing" carries with it ambiguous overtones. At its worse, remixing is a way to give some new shell life to a past musical recording in order to generate continued income for washed-out rockstars and their mercenary record companies. Or sometimes a piece of music is remixed into a new song in a way that rips off the original artist both aesthetically and financially. But at its best, remixing is a matter of "revoicing", allowing the original song to be sung again in a contemporary context that is culturally and aesthetically different. Such a remixing honours and respects the integrity and brilliance of the original piece whilst helping it to be heard anew in the ears and lives of people with different cultural sensibilities. ${ }^{16}$

The (southern) African generation of black young activists and subsequent cohorts have been shaped by these type of art forms within popular culture, as enter-

${ }^{13}$ For a broader discussion of how I utilise this concept see Reggie Nel, "Remixing a Postcolonial Missiology to the beat of Frantz Fanon and Steve Biko", Swedish Missiological Themes 99 (2011), 427-430 and Reginald W. Nel, Discerning an African Missional Ecclesiology in Dialogue with two Uniting Youth Movements (Unpublished Doctoral Thesis, Pretoria: University of South Africa, 2013), 45-51.

${ }^{14}$ Cf. Boitumelo B Senokoane and Johannes (Klippies) Kritzinger Tambach Remixed: 'Christians in South African Society, (Paper presented at the NTS Conference on reading the classics, 2007); Whilst not directly referring to remixing, see also the argument of James Cone, "The Spirituals and the Blues: An Interpretation", (Westport: Greenwood Press, 1972) on how popular art, in particular the performing of the spirituals and the blues in the US context of slavery and racism, forms the bedrock of his formation as a theologian, but also his theology. See also, Doug Gray, "Remixing the Church: The five moves of emerging ecclesiology", (London: SCM Press, 2011); Tim Keel, "Intuitive Leadership: Embracing a paradigm of narrative, metaphor and chaos", (Grand Rapids: Baker Books, 2007), 112-115; Dave Rahn and Terry Linhart, "Evangelism Remixed: Empowering students for couragious and contagious faith", (Grand Rapids: Zondervan, 2009).

${ }^{15}$ Brian J Walsh and Sylvia C Keesmaat, "Colossians Remixed: Subverting the empire", (Downers Grove, III, InterVarsity Press, 2004).

${ }^{16}$ Walsh and Keesmaat, Collossians Remixed, 7. 
tainment, but also an expression of resistance in the struggle against colonialism ${ }^{17}$. As indicated earlier, whilst they wrestled politically, with structural realities like colonialism and imperialism, as it was dictated to them through the education system and also the missionary faith tradition, culturally, they were moving and dancing, unofficially yet unashamedly, and defiantly to their remixes - their black heartbeat.

This impacted also the faith-based youth ministry in this context, to become particular expressions of youth activism. Here, apart from the remixing of the official hymns and popular spirituals in liturgical performances in worship services, camps and youth congresses, Koopman ${ }^{18}$ also shows that, in the context of theological ethics and moral formation, this led to the recognition that faith-based youth ministry as youth activism, should challenge Christian ethics to recognise that in order to develop good people, it also need to work towards good rules ${ }^{19}$. He explains this interaction,

... youngsters should be schooled how to intervene in the law-making process. Which bills (laws in concept) are to be tabled in the law-making institutions, what stance should a Christian take, should submissions be done, should the public be informed and influenced and how this should be done...The task of youth ministry is not met when these challenges are met.... The challenge of forming or building the players who are not only capable of making good rules, but who also live by those rules - that is the task of moral formation - is on the table of the youth ministry. ${ }^{20}$

What was critical from this trajectory was therefore to affirm how the activism of younger people impacted on specific political processes, but also their own moral (spiritual) formation through the remixing of traditional church culture, and that this combination strengthened their agency to meaningfully transform society, including theology. Within this context the theological discipline which directly related to black churches, Missiology in particular, was on a journey of transformation, from a colonialist Science of Missions ("Sendingwetenskap") towards what I would tentatively call, Postcolonial Missiology, or simply Postcolonial Theology. This challenge from youth activists also shaped to a large degree the formation of

17 Biko, I write what I like, 50.

18 Nico N Koopman, "Good Games need Good Rules and Good People", in Youth Ministry: The basics and beyond. Youth specialists explore the challenges of ministry in the 21st century, edited by Deon Kitching and Duffy Robbins, (Wellington: Youth Specialties, 1997), 87-88.

${ }^{19}$ See also Tony Campolo, "Reflections on Youth Ministry in a Global Context: Taking Seriously the Least of These", in Starting Right: Thinking theologically about youth ministry, edited by Kenda Creasy Dean, Chap Clarke and Dave Rahn (Grand Rapids MI, Zondervan Publishing House, 2001), 91-101.

${ }^{20}$ Koopman, Good Games, Good Rules and Good People. 88. 
the various expressions of Liberation Theologies - in the case of Africa and South Africa, Critical African theology, Feminist Theology and South African Black Theology in particular.

\section{Intercultural Theology, as a response.}

It was in response to this turn, where Wijsen and others, proposed the notion of Interculturality for renaming, replacing, or simply supplementing the embarrasing term Missiology with what they call, Intercultural Theology ${ }^{21}$. The Declaration of 12 September 2008, on Mission as Intercultural Theology defines it as a subject,

... from a wide theological perspective - focusses on the encounters and disputes between Christianity and non-Christian religions, as well as on theological reflections about the non-western cultural dialects of Christianity in close connection with the general question of ecumenism. ${ }^{22}$

They call this proposal, "a new attempt to do justice to local theologies and particular experiences of churches within the universal church"23. The background for this shift, Wijsen points out, was, according to the assessment from the Association of the Universities in the Netherlands, the danger of "an overtly introspective Eurocentrism"' ${ }^{4}$ in their theology. He calls Intercultural Theology a "new perspective and a new method in theology"25, which is grounded in three developments ${ }^{26}$, namely, firstly, the shift of gravity, in the numbers of Christians from the West to the global South, and therefore the questioning of the presumption of European theology to be universally valid. Within this shift it is recognised that all theologies are contextual and local. Secondly, he refers to the challenge from within, i.e., the secular philosophies in European society and academia itself, which marginalised the Christian frame of reference in the public sphere and, with the acceleration of globalisation and migration, also the growing reality of multiculturalism and religious plurality. Lastly, he refers to the recognition by the Second Vatican Council that all (local) churches, are to be self-reliant, mature and local in all aspects of

${ }^{21}$ Frans Wijsen, “Intercultural Theology and the Mission of the Church”, Exchange 30, no.3 (2001), 218228; "Mission Studies as Intercultural Theology and its Relationship to Religious Studies", Declaration of 12 September 2005, Mission Studies 25 no.1 (2008), 103-108; Ken C. Miyamoto, A Response to "Mission Studies as Intercultural Theology and Its Relationship to Religious Studies", Mission Studies 25 (2008), 109-110; Werner Ustorf, The Cultural Origins of 'Intercultural Theology'”, Mission Studies 25, no.2 (2008), 229-251.

${ }_{22}$ Mission Studies as Intercultural Theology, 104.

${ }^{23}$ Wijsen, Intercultural Theology and the Misson, 222.

${ }^{24}$ Wijsen, Intercultural Theology and the Misson, 218.

${ }^{25}$ Wijsen, Intercultural Theology and the Misson, 221.

${ }^{26}$ Wijsen, Intercultural Theology and the Misson, 221-222. 
their existance, including their theology, however the challenge remained on how they are to relate to each other, as one, holy catholic church. It is, for Wijsen, in response to these developments that Intercultural Theology is proposed.

Ustorf ${ }^{27}$ also speaks of the turn to Intercultural Theology as one of the "acts of theological repentance in the North" ${ }^{28}$ and see 1975 as year where the intercultural and theological were explicitly related for the first time. For him, it is not only about the discovery that all theologies are contextual, but he places the emphasis on the "much older Northern theological fault-lines" which surfaced "under the pressure of the decolonialisation" ${ }^{29}$. For him, the names of Hans Jochen Margull, Walter Hollenweger and Richard Friedli, who in the seventies was, "advocates of ... a de-colonized theology that would include those traditions that were usually neglected by Western theology - non-Western and/or non-literary traditions" ${ }^{30}$, as crucial in understanding the genesis of Intercultural Theology and it has therefor a specific "north-Atlantic origin" - "mainly to be found in the theological discussions of Europe and in the international educational discourse" ${ }^{31}$. Whilst he shows that these discussions took place specifically within Western Europe, mostly in German and later Dutch, in the 1990s it most prominently Robert Schreiter and David Bosch (outside Europe) who entered the debate on terminological clarity, specifically, for Bosch, in a "post-colonial and polycentric period." ${ }^{2}$ The term has been introduced by European and the AngloAmerican debates on culture and context in theology, and he concludes, "Today, the term has not only been widely accepted in Western theology, but in many instances, it completely replaced the terms mission and missiology" ${ }^{33}$ Ustorf is however critical of a superficial "tactical update", which sneaks in exising theological presuppositions and biases. This challenge goes deeper, as an acknowledgement of the discontinuity of "non-Western variants of Christianity" from what was designed in the West, which challenge power structures of the world and requires a "deliberate transgression of traditional theological approaches and methods" 34 .

In searching for a new method Wijsen then straddles between the "intercultural", i.e., between the different cultures. He then defines intercultural hermeneutics as

${ }^{27}$ Ustorf, Cultural Origins, 229.

28 Ustorf, Cultural Origins, 243.

${ }^{29}$ Ustorf, Cultural Origins, 230

30 Ustorf, Cultural Origins, 230

${ }^{31}$ Ustorf, Cultural Origins, 231-232.

${ }^{32}$ Ustorf, Cultural Origins, 232

${ }^{33}$ Ustorf, Cultural Origins, 232

${ }^{34}$ Ustorf, Cultural Origins, 235-236. 
"the theory and the method of interpretation and understanding across cultural boundaries. It deals with the question to what extend 'the others' really differs from 'us', whether and under what conditions the understanding of 'the others' as 'others' is possible" 35 and what he calls, "subaltern hermeneutics", i.e., a "careful analysis of cultural contact and cultural change 'from within' and 'from below"'36.

Whilst one can affirm these reflections, one also need to note that there is a danger of reducing the theological struggles simply to the cultural, leaving behind the political-economic dimensions, which surface again today, under Empire. There is in these proposals a superficial reference to the postcolonial, which is the conscious affirmation and retrieval of liberation discourses, and therefore the intertwinement of the cultural, economic greed and racism. Hence, instead of an Intercultural Theology, I would propose Postcolonial Theology, which is based on an epistemology rooted in intersubjective dialogue, in order to continue the quest for selfidentity and affirmation, towards socio-political, economic, cultural and religious liberation for all. This remixed [southern] African theology emerged out of and engendered the activism as alluded to earlier, but it is challenged again, albeit to a new beat.

\section{Youth Activism to a New Beat}

Its seems that (at least in South Africa) there is a "rhetoric of despair" ${ }^{37}$ in the face of the perceived lack of the youth and students activism, as discussed in a previous section, which has characterized the youth ministry of black South African churches and student movements and theology, since the late 1960s. The initial popular explanation in South Africa of the 1990s was the assertion that "the struggle is over" and that the church should return to its "normal spiritual business". The crucial question is however whether the participation of Christian youth in popular struggles against "the system", and their challenge to theology, was an aberration or whether it was an expression of authentic Christian witness? I am of the view that it is indeed an expression of authentic Christian witness and therefore it follows that the particular theological artistry which guided and sustained this praxis, is still relevant for the purpose of unearthing afresh the authentic expression of a youthful, but more importantly, a postcolonial theological agenda for today. It seems that in the literature in the disciplines of Practical Theology and Youth Ministry ${ }^{38}$

${ }^{35}$ Wijsen, Intercultural Theology and the Mission, 224.

${ }^{36}$ Wijsen, Intercultural Theology and the Mission, 225.

37 I borrow this phrase from Youth Ministry scholar, Kenda Creasy Dean, "The New Rethoric of Youth Ministry", Journal of Youth and Theology 2 no.2 (2003), 8-18

38 Youth Ministry, as academic discipline is still in its infancy, having been forged within the discipline of Practical Theology, under the rubric of Christian Education. The establishment of the International 
- which traditionally deals with younger people in faith communities, there remains a dearth of analysis of the various expressions of youth activism, in their quest for an authentic public witness. Whilst there is a plethora of research output on the liberation theologies, and various practical proposals for church in the "new South Africa", studies into the new struggles of youth activism in the postcolony remains scarce. New experiments and frameworks are needed for a new audience and a new set of challenges - a remixing.

The anecdotal reference to the "Arab Spring" in the opening paragraphs graphically depicts the way youth activism, as an integral part of waves of social movements, continues to challenge domination, albeit to a new beat. These events in the some [northern] African countries, like Tunisia, Egypt and Libya, but also Middle Eastern countries, like Iran, Turkey and Syria cannot be ignored or merely isolated to these regions and therefore dismissed as "Islamic fanaticism", or youthful naiveté. These eruptions, as diverse as it is, often sparked off by local dynamics, is an integral part of a bigger matrix ${ }^{39}$, of what is called "the network society" 40 or what others would refer to as a "technocratic, state-centred, privatised and neo-liberal" world. Chomski speaks of these simply as "revolt against the Empire"42. Further, these struggles are also (uncharacteristically) interreligious. The deeper understanding of the eruptions of young people, through social movement studies lens happens in continuity with the tradition and "spirit" of youth activism as explicated in earlier, yet there is something new - different, which prompt scholars to refer to "new" social movements ${ }^{43}$, in the face of new expression of imperialism.

What is this "new beat"? Larana, Johnson and Gusfield, in their research on new social movements, show that in the student movements of the 1960s, as referred to in the previous section, there was already the "seed" which challenged the classic

Association for the Study of Youth Ministry (IASYM), an interdisciplinary international society, with her journal the Journal for Youth and Theology (JYT) inaugurated a new self-understanding suggesting a growing autonomous body of knowledge and methodologies.

39 Noam Chomski, "Why the Mid-East Turmoil is a direct threat to the American Empire", http://www. alternet.org/story/149786/chomsky\%3A_why_the_mideast_turmoil_is_a_direct_threat_to_the_ american_empire [Accessed 3 Feb 2011]; Manuel Castells, "The Network Society", (Massachusetts: Blackwell, 2011),

${ }^{40}$ Manuel Castells, "The Network Society", refers to movements in various parts of the world, and also the "Occupy Wall Street" movements, as fundamentally driven by student protests. See also, Joerg Rieger

${ }^{41}$ Ignatius Swart and Stephan De Beer, "Doing urban public theology in South Africa: Introducing a new agenda", HTS Theological Studies, 70:3 (2014).

42 Chomski, Why the Mid-East Turmoil is a direct threat to the American Empire

${ }^{43}$ Enrique Larana, Hank Johnson and Joseph R. Gusfield, "New Social Movements: From Ideology to Identity", (Philadephia: Temple University Press, 1994); Greg Leffel, "Faith seeking Action: Mission, Social Movements, and the Church in Motion", Lanham, Toronto, Plymouth: Scarecrow Press, 2007); 
paradigms in understanding social movements ${ }^{44}$. These paradigms was focused on theories of ideology, which means primarily how the political-economic structure determined their formation and agenda, whilst in new social movement (NSM) studies $^{45}$, there is also an emphasis on the cultural, i.e., how innovative and creative negotiations of meaning-making and identity formation becomes a public force for transformation. For them,

... the grand tradition of the Left has both been an integral part of how generations of activists have thought about themselves and a transcendent view of what society could be. This tradition was internalized into one's social identity; it was lived in one's daily contacts and through the content of that interaction. Although ideology, grievances and collective identity are analytically separate, there is a strong relationship between them, one that has been muted in the past but has been brought into the theoretical foreground by NSM research. ${ }^{46}$

They continue,

This "epistemological reframing" would permit a deeper approach to the study of social movement formation that draws on the latent, non-visible, cognitive dimensions instead of visible and political aspects. ${ }^{47}$

This is relevant for the way we do Theology, with a explicit intercultural dimension today. In his study of what he calls, the "Emerging Church Movement", Practical Theologian, Tony Jones ${ }^{48}$, use these insights and shows seven characteristics of NSM's which makes it relevant, not only for remixing political social movements, but also for theology. These movements are, for Jones, characterised firstly by the fact that it transcends class structure, as in the case of the broader ecological movement; the background of participants "find their most frequent structural roots in diffuse statuses such as youth, gender, sexual orientation ..."49 Secondly, these movements embody a "plurality of ideas and values ... they tend to have pragmatic orientations and search for institutional reforms that enlarge the system of members' participation in decision-making" ${ }^{50}$, whilst thirdly, these ideas and values of-

\footnotetext{
${ }^{44}$ Larana et al, "New Social Movements", Loc. 43 [Kindle Edition]

${ }^{45}$ Larana et al, "New Social Movements"; Sidney Tarrow, "Power in Movement: Social Movements and Contentious Politics", (Cambridge: Cambridge University Press, 2003[1998]), 207.

${ }^{46}$ Larana et al, "New Social Movements", Loc. 253[Kindle Edition]

${ }^{47}$ Larana et al, "New Social Movements", Loc. 296[Kindle Edition]

${ }^{48}$ Tony Jones, "The Church is Flat: The Relational Ecclesiology of the Emerging Church Movement", Minneapolis: The Jopa Group, 2011)

49 Jones, "The Church is Flat", 13

50 Jones, "The Church is Flat", 14
} 
ten centre on the personal, symbolic concerns of identity and status. In this respect, a fourth characteristic is the fact that NSM's also include as critical in social movement formation and activism, the personal behaviour of individuals. This is because there is, fifthly a shift from an exclusive focus on structural realities to also include (in for example movements for gender, gay and abortion rights) what Jones calls, "the most intimate aspects of human life: sexuality, habits of consumption, and careers" ${ }^{51}$. Jones shows that from the "popular culture venues like Saturday Night Live and the blogosphere" to "anti-globalisation protests at the G8 Summit, World Bank, and International Monetary fund meetings" ${ }^{\prime 2}$ (in the streets) younger generations express their discontent. Hence, in pointing to a next sixth characteristic, it is not surprising that Jones speaks of the new forms in which NSM's organise themselves, "in contrast to cadre-led and centralised bureaucracies of traditional mass parties". Here the emphasis is on a myriad of diffuse and decentred, local, organic cells and forms, which are connected loosely, in a solidarity network. The communication and the links between these, happens via "advanced forms of technology and mass communication as a mobilizing tool and conduit to alternative forms of media" ${ }^{\prime 3}$. In this respect he highlights lastly, the role of social media in relation to presidential campaigns, but also "the revolts around the Iranian presidential election of 2009 and 2010," as examples of the "proliferation of social media" 54 .

Whilst Jones' appropriation of the insights from NSM research, may seem repetitive, and his bearing a distinct North American bias, it does help to connect concretely a NSM frame of reference, to the social transformations unfolding globally in terms of the Network society. It draws the notions of the cultural, or better, the intercultural, as a crucial dimension, but also medium into the ambit of the theological. Indeed the public and personal divide becomes less of a concern, whilst the intercultural becomes inherent in the task of doing Theology today. These new waves of young activists, in their revolt against empire, mix up public and personal, political and cultural, the local and global, which goes beyond the old binaries.

\section{Conclusion}

Whilst the notion "intercultural" becomes critical, in the light of the previous discussion, it cannot mean a "softening" or reduction of the hard-core realities of neocolonial conquest and imperialism, into a benign, multi-culturalism, which reduce the existential political and economic struggles against oppression to the cultural. The intercultural turn can carry the danger of easing out an praxis-based episte-

51 Jones, "The Church is Flat", 16

52 Jones, "The Church is Flat", 16

53 Jones, "The Church is Flat", 18

54 Jones, "The Church is Flat", 20 
mology of struggle in the face of Empire as expressed in the (older) expressions of youth activism. One have to also take serious the complex reality postcoloniality, as it helps to deal with the history and current reality of the postcolony, as it continues to manifest itself in the neoliberal society. The terms "intercultural", but then also "anti-racist", "interreligious", "affiring and inclusive", "public", liberational, etc., would be different key dimensions to temper and guide the dialogue, but also the concrete contestations, amongst various expressions of Postcolonial Theology. This understanding enable us to do a Postcolonial Theology for the sake of social transformation.

The new "anonymous, persistent struggles" of new generations not only remix their worlds, they also challenge the way we would do a Postcolonial Theology today. It is intercultural, public, anti-racist, even interreligious. It is liberative and transformative. This is what is remarkable about how young activists are (again) transforming their worlds - this is indeed a theological season of Spring. 